\title{
Well-Being and Social Media: A Systematic Review of Bergen Addiction Scales
}

\author{
Mirko Duradoni ${ }^{1}$ (D) Federico Innocenti ${ }^{2}$ and Andrea Guazzini ${ }^{2,3, *(D)}$ \\ 1 Department of Information Engineering, University of Florence, 50139 Florence, Italy; \\ mirko.duradoni@unifi.it \\ 2 Department of Education, Literatures, Intercultural studies, Languages and Psychology, University of \\ Florence, 50135 Florence, Italy; innocentifederico.97@gmail.com \\ 3 Centre for the Study of Complex Dynamics (CSDC), University of Florence, 50135 Florence, Italy \\ * Correspondence: andrea.guazzini@unifi.it
}

Received: 9 January 2020; Accepted: 24 January 2020; Published: 29 January 2020

\begin{abstract}
Does social media addiction impair the well-being of non-clinical individuals? Despite the Internet being able to be considered as a promoting factor for individual empowerment, previous literature suggests that the current massive availability of Information and Communication Technologies (ICT) may be dangerous for users' well-being. This article discusses the relationship between the most used social media addiction measures (i.e., the Bergen Facebook Addiction Scale-BFAS, the Bergen Social Media Addiction Scale-BSMAS) and well-being. A systematic review considering all the publications indexed by PsycInfo, PsycArticles, PubMed, Science Direct, Sociological Abstracts, Academic Search Complete, and Google Scholar databases was performed to collect the data. Ten of 635 studies were included in the qualitative synthesis. Overall, most of the included works captured a negative but small relationship between BFAS/BSMAS and well-being, across multiple definitions and measurement.
\end{abstract}

Keywords: well-being; Bergen Facebook addiction scale; Bergen social media addiction scale; social media addiction

\section{Introduction}

Information and Communication Technologies (ICTs), in the age of Internet of Things, increasingly affect and frequently determine people's everyday lives [1,2]. Through these technologies, we can access the Internet and social media at any moment we like and in many countries across the world [3] in order to have informational or identity support and capital. On social media such as Facebook, Twitter, Instagram, or Tik Tok, people are engaged in a whole series of activities, which encompass entertainment (e.g., playing games, passing time, fighting boredom), social activities (e.g., communicating, socializing, self-disclosing, keeping in touch with relevant virtual social communities, maintaining offline networks), and identity needs (e.g., building a virtual social identity) [4-8], and providing health information [9].

Given the attractiveness and availability of social media, people are becoming more and more connected to them both in terms of engagement (e.g., time spent) and presence (e.g., SNs accounts owned) [10-12]. In other words, social media are becoming a "normal" part of our contemporary lives [13].

Together with the increasing usage of such media, scholars observed that excessive Internet, gaming, or social media use could be associated with addiction $[14,15]$ and other psychiatric comorbidity (e.g. depression, alcohol abuse) [16].

Although the diagnostic framework is not entirely clear in the Diagnostic and Statistical Manual of Mental Disorders (DSM-5) [17,18], other researchers define Internet and social media addiction as 
compulsive use and withdrawal, craving, tolerance, interpersonal and health-related problems [19,20]. The Internet and social media users may expect a lower quality of life and well-being [21] due to having problems with self-care, difficulty in performing daily routines, suffering from pain and discomfort, anxiety, and depression [22].

Nonetheless, the contributions concerning the relationship between social media addiction (especially Facebook) and well-being have not yet been systematized accounting for the multiple conceptualizations and, thus measures, of well-being adopted across studies. The aim of this article is to offer a systematic review of empirical evidence connecting the Bergen Facebook Addiction Scale-BFAS [23] and the Bergen Social Media Addiction Scale-BSMAS [24], with well-being. Moreover, the size and direction of the relationship between well-being and social media addiction measured through Bergen's addiction scales will be identified and discussed. As it emerges from the literature, we expect a negative relationship between the two constructs [3,25-27].

The paper is organized as follows. In the "method and procedures" section, BFAS and BSMAS measures will be presented together with the rationale behind their development. The systematic review methodology and inclusion/exclusion criteria will be described after. In the results section, the included studies will be analyzed and presented in two separate paragraphs. The first one will include the studies that relied on well-being definitions that fall within the dichotomy hedonic-eudaimonic well-being. The second one will instead encompass all the works that are not attributable to this classification. Finally, the results will be critically discussed in the last section.

\section{Method and Procedures}

In this section, details about BFAS and BSMAS are provided, including psychometric properties and the rationale behind their construction, since the two scales are the central topic of this systematic review.

The authors searched all the studies that included relationship BFAS/BSMAS with well-being as described in the article methodology. The inclusion and exclusion criteria are spelled out in detail in the dedicated section, which also tracks the information flow through the review process.

\subsection{Measuring Facebook and Social Media Addiction}

The study of Internet addiction phenomena grew along with the availability of ICT technologies. Since the late 1990s, researchers have investigated whether people became addicted and developed Internet-related addiction measures [28,29]. As Facebook became more popular across broad segments of Internet users [30], dedicated measures were needed. For example, the Addictive Tendencies Scale was developed [31]. Nonetheless, it failed to consider all of the addiction's core components. To overcome this limitation, the Bergen Facebook Addiction Scale [23] was constructed. The scale is composed of six items, each of them reflecting one core aspect of addiction [32-35], namely: (a) salience (i.e., the activity controls thinking and behavior), (b) mood modification (i.e., the activity is carried on to improve mood), (c) tolerance (i.e., increasing amounts of the activity are needed overtime), (d) withdrawal (i.e., unpleasant feelings emerge when the activity is reduced or interrupted), (e) conflict (i.e., the activity interferes in relationships and other activities), and (f) relapse (i.e., the tendency to return to earlier levels of the activity after abstinence).

The BFAS shows an adequate dimensionality $\left(\chi^{2} / \mathrm{df}=1.84 ;\right.$ Comparative Fit Index $[\mathrm{CFI}]=0.99$; Root Mean Square Error of Approximation [RMSEA] = 0.05) [36] and reliability (Alpha coefficient is 0.83) [37]. For this reason, BFAS has been adopted and used as a psychometrically sound instrument for measuring Facebook-related addiction. Indeed, at the time of writing, the "Web of Science" tracking system reports 310 citations for BFAS, while Google Scholar 893.

Despite the undoubted utility of the instrument, the Bergen Facebook Addiction Scale risks being too specific in the current environment in which social media proliferates and Facebook is no longer the only one on the pitch [38,39]. For this reason, BSMAS was developed to capture the totality of all social network sites [24]. Although maintaining the same rationale (i.e., addiction criteria) and items' main structure, BSMAS uses the words "social media" instead of the word "Facebook" with social 
media being defined as "Facebook, Twitter, Instagram and the like". For the sake of clarity, we specify that in the literature "Bergen Social Networking Addiction Scale" (BSNAS) has been reported as an alternative name for this instrument's version. In any case, the internal consistency of the BSMAS results high $(\alpha=0.88)$, while dimensionality information is currently missing but assumed similar to BFAS. Although Bergen's addiction scales were related to addiction's negative outcomes (e.g., poor sleep quality, anxiety, depression), well-being measures were not adopted as validity measures in the original works for BFAS, BSMAS, and BSNAS, but were rather tested in subsequent studies.

\subsection{Search Strategy}

We relied on an adapted version of the systematic qualitative review approach [40] to select the sources to include and discuss in our article. As a first step, we asked academic information specialists to search for BFAS, BSMAS, and BSNAS scientific studies encompassing international books, articles, reference works, conference papers, and Ph.D. theses. The specialists completed their task using the EBSCOhost platform and consulting the databases of PsycInfo, PsycArticles, PubMed, Science Direct, Sociological Abstracts, and Academic Search Complete. The authors on their part contributed to the search by consulting Google and Google Scholar to increase the chances of identifying the widest range of sources possible. Moreover, we inserted in our preliminary database all the scientific works that cited the articles in which BFAS, BSMAS, and BSNAS were presented for the first time using Web of Science, Scopus, and Google Scholar tracking system. The sources coming from academic information specialists and the authors have been merged in a single dataset and the duplicate sources were removed. The final dataset was set-up with only peer-reviewed sources in which Bergen's addiction scales were empirically tested along with well-being measures. At this stage, full-texts were required for all the work included in the dataset. Furthermore, we specify that we included in the final dataset only sources written in Italian or English.

\subsection{Inclusion and Exclusion Criteria}

Of the 635 results obtained during the screening phase, only 76 mentioned the words "well being", "well-being" or "well-being" in the title, abstract or keywords, and thus were eligible.

Among the 76 results, 49 were excluded because BFAS, BSMAS, or BSNAS were not used but only mentioned. Eight other sources were also excluded because no suitable measure of well-being was employed. Indeed, in these eight studies, well-being was not defined according to the World Health Organization (WHO) definition [41]. WHO refers to health as a state of complete physical, mental and social well-being and not merely the absence of disease or infirmity. Thus, for instance, those studies that refer to well-being as a lack of psychological conditions (e.g., depression) were excluded. Only the sources written in Italian or English were included, so five more results were excluded because they were written in other languages. The other four papers were excluded because data analysis was not suitable for the systematic review process (e.g., lack of descriptive statistics, no correlation coefficients provided for the variables of interest). Finally, it was possible to identify 10 studies that describe the correlation between BFAS or BSMAS or BSNAS, and some measure of well-being [15,42-50].

The flow diagram of the study has been shown in Figure 1. 


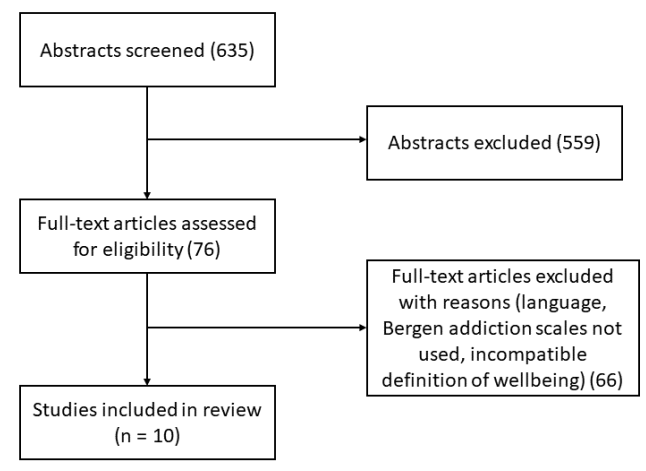

Figure 1. Diagram showing the flow of information through the review: the number of records identified, included and excluded, and the reasons for the exclusions.

\section{Results: Facebook and Social Media Addiction Effects on Well-Being}

Various conceptualizations and measures of well-being have been provided over the years [51-54]. For the sake of clarity, we decided to present the included studies' results in two dedicated sub-sections, considering whether the studies relied on well-being measures that fall within the cluster hedonic-eudaimonic or not.

\subsection{Hedonic and Eudaimonic Well-Being}

Historically, the multi-dimensional construct of well-being [55] has been categorized by psychologists [56] into two clusters: hedonic well-being (HWB) and eudaimonic well-being (EWB) [57-59]. HWB is usually represented by two main aspects: a cognitive evaluation component (i.e., satisfaction with life) [60] and an affective evaluation component (i.e., the prevalence of positive emotions over negative emotions) [61]. Instead, EWB is rather framed in terms of individuals' optimal functioning and self-realization (e.g., meaning in life, flourishing) [58,62-65].

In our dataset, six studies $[15,43,45,47-49]$ employed a well-being measure that falls into the hedonic well-being framework. BFAS (or the version for Weibo) was used in all of them. Three studies $[15,47,48]$ investigated the relationship of Facebook addiction with satisfaction with life (i.e., cognitive evaluation component of HWB) reporting a Person's $r$ coefficient ranging from -0.324 to -0.11 . For the sake of clarity, Pearson's $r$ is interpretable as it follows [66]: we have a negligible correlation for coefficient lower than $|0.30|$, a low correlation for values between $|0.30|$ and $|0.50|$, a moderate correlation for $\mathrm{r}$ values ranging from $|0.50|$ to $|0.70|$, a high correlation for coefficients between $|0.70|$ and $|0.90|$, and a very high correlation for values ranging from $|0.90|$ to $|1.00|$. Thus, in our case, we have a small (from negligible to low) negative correlation between BFAS and people's satisfaction with life. The effect size of BFAS on Life Satisfaction is roughly estimated as ranging from $1.2 \%$ and $10 \%$ across the three studies. Interestingly, in Wang, Gaskin, Wang and Liu [15], for people that do not excessively use Weibo social media, the correlation value is 0.05 and resulted in being not statistically significant, which highlights the absence of any sort of linear relationship between addiction and well-being.

Satici and Uysal study [48], together with Satisfaction with Life, also employed other two hedonic well-being measures, namely: The Subjective Happiness Scale (SHS) [67] and the Subjective Vitality Scale (SVS) [68]. Both scales presented correlation values around -0.30 . More precisely, -0.287 for happiness and -0.32 for vitality. A further measure related to the cognitive component of HWB has been derived from the World Health Organization Quality of Life (WHOQOL) Brief scale [69] and asks people to rate their perceived quality of life [70]. In Atroszko and colleagues'work [43], the relation between BFAS and Quality of life resulted in being negligible (i.e., Pearson's $r=0.07$ ).

In our dataset, three studies $[45,47,49]$ investigated the BFAS relationship with the affective component of HWB. These works each employed a different instrument for assessing well-being, which were the Positive and Negative Affect Schedule (PANAS) [61], the Activation-Deactivation Adjective Checklist (ADACL) [71], and the WHO-5 Well-Being Index [72]. 
Three studies investigated how BFAS affects the affective component of HWB. Two out of three works $[45,47]$ found statistically significant but negligible correlations. In particular, BFAS entertained a negative relationship with positive affect and a positive one with the negative affect component, both measured by the Positive and Negative Affect Schedule (PANAS), while the Activation-Deactivation Adjective Checklist (ADACL), which explores at the same time positive and negative feelings, correlated -0.10 with BFAS [45].

A different result emerged in Turel et al. [49], in which BFAS accounted for approximately $32 \%$ of the variance in the World Health Organization Five Well-Being Index (WHO-5) score.

Finally, only one study put together EWB and BFAS [48] using the Flourishing Scale [62]. The flourishing definition encompasses purpose in life, self-esteem, positive relationships, competence, engagement, optimism, and contribution toward the well-being of others [63,64]. Even in this case, BFAS achieved a small negative correlation (i.e., Pearson's $r=-0.287$ ).

\subsection{Other Well-Being Measures}

The distinction rooted in philosophy between HWB and EWB does not necessarily translate well to science [73]. For this reason, the relationship between Facebook/Social Media Addiction and well-being was also explored relying on other well-being measures. These measures distinguish themselves from the previous in several ways. Measures like the Positive Mental Health Scale (PMH-Scale) [74] take at the same time both the hedonic and the eudaimonic approaches into account, while the Wellbeing Process Questionnaire (Student WPQ) [75] and Ryff's Psychological Well-Being scale (PWB) [76] use psychosocial concepts to assess well-being in a more comprehensive manner. Psychological well-being is defined in terms of human functioning and thus in some way is very close to EWB, but also encompasses typical aspects of HWB (for instance, the cognitive evaluation of one's life) [77].

Overall, four studies used well-being measures that did not fall within the dichotomy HWB and EWB $[42,44,46,50]$. The PMH scale showed a negative linear relationship with BFAS (Pearson's $r=$ $-0.27)$ [44].

A similar result emerged from the Alheneidi work [42], which employed the Student WPQ measure to assess well-being's relationship with social media addiction. BSMAS presented a positive linear correlation with the negative well-being score from the Student WPQ (i.e., Pearson's $r=0.28$ ), a smaller correlation with the positive well-being (i.e., Pearson's $r=-0.13$ ), while no relationship emerged with the positive appraisal which represents people's life satisfaction (i.e., Pearson's $r=0.06$ ). For the sake of clarity, we specify that scores of depression, negative affect, and anxiety define the negative well-being in the Student WPQ, while the positive well-being is described by both positive affect and positive appraisal.

The same author tested the same relationships with a sample of workers employing the dedicated WPQ version [78], obtaining quite similar results. Negative well-being showed a higher correlation with BSMAS (i.e., Pearson's $r=0.45$ ). The relationship between BSMAS and positive well-being resulted in a lower and not statistically significant Pearson's $r$ value (i.e., $r=0.03$ ). No information was directly provided for the positive appraisal; nonetheless, since neither the positive well-being (which is the composite measure of positive affect and appraisal) nor the positive affect (i.e., Pearson's $r=0.06$ ) presented statistically significant correlation values, we can assume that also in this case BSMAS did not appear to affect people's life satisfaction.

A further study [50] has investigated the relationship between BSMAS and well-being employing the Ryff's Psychological Well-Being Scale, showing a small negative correlation (Pearson's $r=-0.34$ ). BFAS was also put in relation to psychological well-being but only accounting for the relational aspect (i.e., positive relations with others dimension) of the Ryff's scale [46]. In this case, a very small (i.e., negligible) correlation (Pearson's $r=-0.13$ ) was reported with BFAS scores.

In Table 1, the full picture of the relationships entertained by Bergen's addiction scales with well-being measures in the included studies is presented. 
Table 1. The ten studies included in which the well-being measures have been used jointly with BFAS or BSMAS.

\begin{tabular}{|c|c|c|c|c|c|c|c|}
\hline ID & Author & Year & Country & $\begin{array}{l}\text { Sample } \\
\text { Size }\end{array}$ & Sample Description & Measure of WB & $\begin{array}{l}\text { Correlation } \\
\text { Coefficient }\end{array}$ \\
\hline \multicolumn{8}{|c|}{ Bergen Facebook Addiction Scale (BFAS) } \\
\hline 1 & $\begin{array}{l}\text { Turel and } \\
\text { Gil-Or }\end{array}$ & 2018 & Israel & 215 & $\begin{array}{c}\text { Israeli college } \\
\text { students (age range: } \\
\text { 20-65; M-age = 26.99) }\end{array}$ & $\begin{array}{l}\text { WHO five item Wellbeing } \\
\text { Index (WHO-5; [72]) }\end{array}$ & $-0.57^{* *}$ \\
\hline \multirow{4}{*}{2} & \multirow{4}{*}{$\begin{array}{l}\text { Satici and } \\
\text { Uysal }\end{array}$} & \multirow{4}{*}{2015} & \multirow{4}{*}{ Turkey } & \multirow{4}{*}{311} & \multirow{4}{*}{$\begin{array}{c}\text { Turkey university } \\
\text { students (age range: } \\
\text { 18-32; M-age = } 20.86 \\
\text { years) }\end{array}$} & $\begin{array}{l}\text { The Satisfaction with Life } \\
\text { Scale (SWLS; [60]) }\end{array}$ & $-0.32^{* *}$ \\
\hline & & & & & & Flourishing Scale [62] & $-0.29 * *$ \\
\hline & & & & & & $\begin{array}{l}\text { Subjective Happiness } \\
\text { Scale (SHS; [67]) }\end{array}$ & $-0.32 * *$ \\
\hline & & & & & & $\begin{array}{l}\text { Subjective Vitality Scale } \\
\text { (SVS; [68]) }\end{array}$ & $-0.32 * *$ \\
\hline 3 & $\begin{array}{c}\text { Atroszko, } \\
\text { Balcerowska, } \\
\text { Bereznowski, } \\
\text { Biernatowsk, } \\
\text { Pallesen, and } \\
\text { Andreassen }\end{array}$ & 2018 & Poland & 1157 & $\begin{array}{c}\text { Gdańsk full-time } \\
\text { university students } \\
\text { (M-age =20.33 years) }\end{array}$ & $\begin{array}{l}\text { Adapted WHOQOL Brief } \\
\text { scale - Quality of life [70] }\end{array}$ & $-0.07 *$ \\
\hline 4 & $\begin{array}{l}\text { Wang, Gaskin, } \\
\text { Wang and Liu }\end{array}$ & 2016 & China & 915 & $\begin{array}{c}\text { College students } \\
\text { China (M-age }=19.87)\end{array}$ & $\begin{array}{l}\text { Satisfaction with Life } \\
\text { Scale (SWLS; [60]) }\end{array}$ & $\begin{array}{c}-0.11^{* *} \\
\text { (excessive } \\
\text { user of } \\
\text { Weibo) } 0.05 \\
\text { (non-excessive } \\
\text { users) } \\
\end{array}$ \\
\hline \multirow[t]{2}{*}{5} & \multirow[t]{2}{*}{ Satici } & \multirow[t]{2}{*}{2019} & \multirow[t]{2}{*}{ Turkey } & \multirow[t]{2}{*}{280} & \multirow{2}{*}{$\begin{array}{c}\text { University students } \\
\text { (range 17-25; } \mathrm{M} \text {-age = } \\
21.04 \text { years) }\end{array}$} & $\begin{array}{c}\text { Positive and Negative } \\
\text { Affect Schedule (PANAS; } \\
\text { [61]) }\end{array}$ & $\begin{array}{c}\text { Range from } \\
-0.13^{* *} \text { to } \\
-0.18^{* *} \\
\end{array}$ \\
\hline & & & & & & $\begin{array}{l}\text { Satisfaction with Life } \\
\text { Scale (SWLS; [60]) }\end{array}$ & $\begin{array}{l}\text { Range from } \\
-0.16^{* *} \text { to } \\
-0.21^{* *}\end{array}$ \\
\hline 6 & $\begin{array}{l}\text { Brailovskaia, } \\
\text { Teismann, and } \\
\text { Margraf }\end{array}$ & 2018 & Germany & 122 & $\begin{array}{l}\text { German college } \\
\text { students that were } \\
\text { Facebook users (age } \\
\text { range: } 17-38 \text { ) }\end{array}$ & $\begin{array}{l}\text { Positive Mental Health } \\
\text { Scale (PMH-Scale; [74]) }\end{array}$ & $-0.27^{* *}$ \\
\hline 7 & $\begin{array}{l}\text { Du, van } \\
\text { Koningsbruggen } \\
\text { and Kerkhof }\end{array}$ & 2018 & $\begin{array}{c}\text { US, } \\
\text { UK, } \\
\text { Canada, } \\
\text { and } \\
\text { Australia }\end{array}$ & 405 & $\begin{array}{l}\text { Prolific platform } \\
\text { users. Age range: } \\
\text { 18-59 years; } \\
\text { M-age=31; }\end{array}$ & $\begin{array}{l}\text { Activation Deactivation } \\
\text { Adjective Checklist } \\
\text { (ADACL; [71]) }\end{array}$ & $-0.10 *$ \\
\hline 8 & Olufadi & 2016 & Nigeria & 1808 & $\begin{array}{c}\text { People from Ilorin } \\
\text { metropolis. Age } \\
\text { range: } 20-58 ; \text { M-age = } \\
32.43\end{array}$ & $\begin{array}{c}\text { Positive relations with } \\
\text { others [76] }\end{array}$ & $-0.13 *$ \\
\hline \multicolumn{8}{|c|}{ Bergen Social Media Addiction Scale (BSMAS) } \\
\hline 9 & $\begin{array}{c}\text { Worsley, } \\
\text { Mansfield, } \\
\text { and Corcoran }\end{array}$ & 2018 & $\begin{array}{l}\text { Not } \\
\text { available, } \\
\text { online } \\
\text { survey }\end{array}$ & 915 & $\begin{array}{l}\text { Social media users. } \\
\text { Age range: } 18-25 ; \\
\text { M-age = 20.19 }\end{array}$ & $\begin{array}{l}\text { 18-item version of Ryff's } \\
\text { Psychological Well-Being } \\
\text { Scales (PWBSs; [76]) }\end{array}$ & $-0.34^{* *}$ \\
\hline \multirow{4}{*}{10} & \multirow{4}{*}{ Alheneidi } & \multirow{4}{*}{2019} & \multirow[t]{2}{*}{ UK } & \multirow[t]{2}{*}{226} & \multirow{2}{*}{$\begin{array}{l}\text { UK-based students } \\
\text { (age range: 18-71) }\end{array}$} & $\begin{array}{l}\text { The Student WPQ [75]: } \\
\text { positive well-being }\end{array}$ & $-0.13 *$ \\
\hline & & & & & & $\begin{array}{c}\text { The Student WPQ: } \\
\text { negative well-being }\end{array}$ & $0.28^{* *}$ \\
\hline & & & \multirow[t]{2}{*}{ UK } & \multirow[t]{2}{*}{254} & \multirow{2}{*}{$\begin{array}{l}\text { UK-based employees } \\
\text { (age range: } 18-65 ; \\
\text { M-age=42) }\end{array}$} & $\begin{array}{l}\text { WPQ short form [78]: } \\
\text { Positive well-being }\end{array}$ & 0.04 \\
\hline & & & & & & $\begin{array}{l}\text { WPQ short form: } \\
\text { Negative well-being }\end{array}$ & $0.45^{* *}$ \\
\hline
\end{tabular}

$*: p<0.05 ; * *: p<0.01$. 


\section{Discussion}

The impact of Information and Communication Technologies (ICT) and Internet services (e.g., social media) on our daily lives [79] can surely be described both in terms of individual empowerment, as well as in terms of direct impact on well-being. Literature reports how people spending significant amounts of time connected on the Internet can experience negative outcomes including problematic and addictive behaviors $[29,35,80]$. Nevertheless, less is known about how measures of social media addiction relate with well-being indicators for non-clinical individuals. Our work contributes with a systematic review in clarifying the relationship emerging by the literature between well-being and Bergen's addiction scales, which are widely adopted by the scientific community as valid measures for social media addiction.

In general, the psychological tools thought to capture negative well-being aspects close to psychopathology (i.e., WPQ-Negative Well-Being, WHO-5) resulted in having the highest correlation with Bergen's addiction scales [42,49], while the other well-being scales appeared to entertain a small or no relationship to BFAS/BSMAS.

The fact that WHO-5 had the highest correlation with BFAS is interpretable considering that the WHO-5 is more sensitive towards dimensions particularly impacted by social media usage, as well as connected to depression and anxiety. For instance, a score below 13 in WHO-5 indicates poor well-being and is an indication for testing for depression [81,82]. In this sense, the instrument's lower bound appears able to capture and distinguish pathological individuals, which may use Facebook or social media in a dysfunctional way $[10,83]$.

Instead, the positive framed well-being measure appeared less connected to BFAS/BSMAS. This effect could be explained considering how low scores on these well-being measures do not necessarily imply psychopathology issues, and thus could be the outcome of social media addiction. Literature highlighted how psychopathological measures of anxiety and depression entertained small or negligible correlation with flourishing [84] and life satisfaction $[85,86]$, which are respectively EWB and HWB measures.

To put it simply, positive and negative framed well-being measures seems characterized by a different sensitivity towards psychopathology, and in particular with anxiety and depression diseases, which have been already connected with a dysfunctional use of social media $[10,83]$. Thus, this may be the reason behind the different magnitudes of the correlation between BFAS/BSMAS and well-being measured considering positive or negative frames. Indeed, we observed an effect size ranging from $20 \%$ to $32 \%$ for the negative framed measures and from $0 \%$ to $12 \%$ for the positive ones. The variability of these effects, as well as their size, can also be rooted in cultural and sample-related differences and thus further research appears as needed to define how much sample characteristics matter. The considered studies were realized in different countries (i.e., within different cultural system), and, in particular, only 4 out of 10 studies $[42,45,46,50]$ assessed the relation between Bergen's addiction scales and well-being with populations different from college students. Future research should consider different populations, and explicitly account for the more relevant moderating and mediating factors (e.g., age, technological fluency and literacy) reported by the recent literature about human virtual dynamics [87-89], as well as lay the foundations for comparative studies involving different populations.

Moreover, how the different motives behind a dysfunctional social media experience (e.g., excessive need for communication, leisure, belonging) affect people's well-being should be tested by new empirical research. The same scores in terms of addiction could underlie very different experiences and thus repercussions on the well-being [90]. The operationalization of well-being is another critical issue. A new multidimensional and wider operationalization of well-being is needed to understand the "real" magnitude of social media addiction's effect on well-being, since social media addiction could impact well-being aspects differently, as it emerged in our work.

A factorial analysis of the current well-being measures could be useful to define new well-being areas and dimensions to study together with social media addiction measures. 
In general, most of the considered works underlined a negative, but small, relationship between BFAS/BSMAS and well-being, measured across multiple definitions (e.g., HWB, EWB, psychological well-being) and tools. Therefore, the broader and pervasive use of ICT, and thus social media, does not clearly appear to associate with severe damage of people's well-being, at least considering the positive framed measures of well-being employed so far. Nonetheless, solutions are called to investigate more deeply, and possibly dampen a possible negative impact of ICT on those populations that would appear more susceptible in terms of well-being. Moreover, the ICTs and social media could represent promoting factors for people's well-being [91-93], whenever the complex connection between digital life, individual, and psychological features would be understood and modeled.

Author Contributions: Conceptualization, M.D. and A.G.; Methodology, M.D., F.I. and A.G.; Investigation, M.D., F.I. and A.G; Data curation, M.D., F.I. and A.G.; Writing-original draft preparation, M.D., F.I. and A.G; Writing-review and editing, M.D., F.I. and A.G. All authors have read and agreed to the published version of the manuscript.

Funding: This research received no external funding.

Conflicts of Interest: The authors declare no conflict of interest.

\section{References}

1. Krasnova, H.; Abramova, O.; Notter, I.; Baumann, A. Why phubbing is toxic for your relationship:

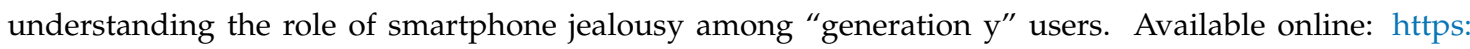
//aisel.aisnet.org/cgi/viewcontent.cgi?article=1130\&context=ecis2016_rp (accessed on 20 November 2016).

2. Ling, R. The Mobile Connection: The Cell Phone's Impact on Society; Elsevier: New York, NY, USA, 2004.

3. Kuss, D.J.; Griffiths, M. Online Social Networking and Addiction-A Review of the Psychological Literature. Int. J. Environ. Res. Public. Health 2011, 8, 3528-3552. [CrossRef]

4. Allen, K.A.; Ryan, T.; Gray, D.L.; McInerney, D.M.; Waters, L. Social Media Use and Social Connectedness in Adolescents: The Positives and the Potential Pitfalls. Educ. Dev. Psychol. 2014, 31, 18-31. [CrossRef]

5. Andreassen, C.S.; Billieux, J.; Griffiths, M.; Kuss, D.J.; Demetrovics, Z.; Mazzoni, E.; Pallesen, S. The relationship between addictive use of social media and video games and symptoms of psychiatric disorders: A large-scale cross-sectional study. Psychol. Addict. Behav. 2016, 30, 252-262. [CrossRef]

6. Misoch, S. Stranger on the internet: Online self-disclosure and the role of visual anonymity. Comput. Hum. Behav. 2015, 48, 535-541. [CrossRef]

7. Moon, J.; Pu, J.; Lawrence, G. The Role of Virtual Social Identity through Blog Use in Social Life. Available online: https://aisel.aisnet.org/cgi/viewcontent.cgi?article=2038\&context=amcis2006 (accessed on 23 December 2006).

8. Ryan, T.; Chester, A.; Reece, J.; Xenos, S. The uses and abuses of Facebook: A review of Facebook addiction. J. Behav. Addict. 2014, 3, 133-148. [CrossRef] [PubMed]

9. Zhang, M.W.; Tran, B.X.; Le, H.T.; Nguyen, H.D.; Nguyen, C.T.; Tran, T.D.; Latkin, C.A.; Ho, R.C. Perceptions of Health-Related Information on Facebook: Cross-Sectional Study Among Vietnamese Youths. Interact. J. Med. Res. 2017, 6, e16. [CrossRef] [PubMed]

10. Guazzini, A.; Duradoni, M.; Capelli, A.; Meringolo, P. An Explorative Model to Assess Individuals' Phubbing Risk. Future Internet 2019, 11, 21. [CrossRef]

11. Huang, C. Time Spent on Social Network Sites and Psychological Well-Being: A Meta-Analysis. Cyberpsychology Behav. Soc. Netw. 2017, 20, 346-354. [CrossRef] [PubMed]

12. Vosecky, J.; Hong, D.; Shen, V.Y. User identification across multiple social networks. In Proceedings of the 2009 First International Conference on Networked Digital Technologies, Ostrava, Czech Republic, 29-31 July 2009; pp. 360-365.

13. Boyd, D.M.; Ellison, N.B. Social Network Sites: Definition, History, and Scholarship. J. Comput.-Mediat. Commun. 2007, 13, 210-230. [CrossRef]

14. Turel, O.; Brevers, D.; Bechara, A. Time distortion when users at-risk for social media addiction engage in non-social media tasks. J. Psychiatr. Res. 2018, 97, 84-88. [CrossRef]

15. Wang, J.-L.; Gaskin, J.; Wang, H.-Z.; Liu, D. Life satisfaction moderates the associations between motives and excessive social networking site usage. Addict. Res. Theory 2016, 24, 450-457. [CrossRef] 
16. Ho, R.C.; Zhang, M.W.; Tsang, T.Y.; Toh, A.H.; Pan, F.; Lu, Y.; Cheng, C.; Yip, P.S.; Lam, L.T.; Lai, C.-M.; et al. The association between internet addiction and psychiatric co-morbidity: A meta-analysis. BMC Psychiatry 2014, 14, 183. [CrossRef] [PubMed]

17. He, Q.; Turel, O.; Brevers, D.; Bechara, A. Excess social media use in normal populations is associated with amygdala-striatal but not with prefrontal morphology. Psychiatry Res. Neuroimaging 2017, 269, 31-35. [CrossRef]

18. Kuss, D.J.; Griffiths, M.; Pontes, H.M. Chaos and confusion in DSM-5 diagnosis of Internet Gaming Disorder: Issues, concerns, and recommendations for clarity in the field. J. Behav. Addict. 2016, 6, 103-109. [CrossRef]

19. Mak, K.-K.; Lai, C.-M.; Ko, C.-H.; Chou, C.; Kim, D.-I.; Watanabe, H.; Ho, R.C.M. Psychometric Properties of the Revised Chen Internet Addiction Scale (CIAS-R) in Chinese Adolescents. J. Abnorm. Child Psychol. 2014, 42, 1237-1245. [CrossRef]

20. Tran, B.X.; Mai, H.T.; Nguyen, L.H.; Nguyen, C.T.; Latkin, C.A.; Zhang, M.W.B.; Ho, R.C.M. Vietnamese validation of the short version of Internet Addiction Test. Addict. Behav. Rep. 2017, 6, 45-50. [CrossRef]

21. Turel, O.; Qahri-Saremi, H. Problematic use of social networking sites: antecedents and consequence from a dual-system theory perspective. J. Manag. Inf. Syst. 2016, 33, 1087-1116. [CrossRef]

22. Tran, B.X.; Huong, L.T.; Hinh, N.D.; Nguyen, L.H.; Le, B.N.; Nong, V.M.; Thuc, V.T.M.; Tho, T.D.; Latkin, C.; Zhang, M.W.; et al. A study on the influence of internet addiction and online interpersonal influences on health-related quality of life in young Vietnamese. BMC Public Health 2017, 17, 138. [CrossRef]

23. Andreassen, C.S.; Torsheim, T.; Brunborg, G.S.; Pallesen, S. Development of a Facebook Addiction Scale. Psychol. Rep. 2012, 110, 501-517. [CrossRef]

24. Andreassen, C.S.; Pallesen, S.; Griffiths, M. The relationship between addictive use of social media, narcissism, and self-esteem: Findings from a large national survey. Addict. Behav. 2017, 64, 287-293. [CrossRef]

25. Longstreet, P.; Brooks, S. Life satisfaction: A key to managing internet \& social media addiction. Technol. Soc. 2017, 50, 73-77.

26. Lin, L.Y.; Sidani, J.E.; Shensa, A.; Radovic, A.; Miller, E.; Colditz, J.B.; Hoffman, B.L.; Giles, L.M.; Primack, B.A. Association Between Social Media Use and Depression Among U.s. Young Adults. Depress. Anxiety 2016, 33, 323-331. [CrossRef] [PubMed]

27. Kross, E.; Verduyn, P.; Demiralp, E.; Park, J.; Lee, D.S.; Lin, N.; Shablack, H.; Jonides, J.; Ybarra, O. Facebook Use Predicts Declines in Subjective Well-Being in Young Adults. PLOS ONE 2013, 8, e69841. [CrossRef] [PubMed]

28. Griffiths, M. Internet addiction: Fact or fiction? The Psychologist 1999, 12, 246-250.

29. Griffiths, M.; Kuss, D.J.; Billieux, J.; Pontes, H.M. The evolution of Internet addiction: A global perspective. Addict. Behav. 2016, 53, 193-195. [CrossRef]

30. Lampe, C.; Ellison, N.B.; Steinfield, C. Changes in Use and Perception of Facebook. In Proceedings of the Proceedings of the 2008 ACM Conference on Computer Supported Cooperative Work; ACM: New York, NY, USA, 2008; pp. 721-730.

31. Wilson, K.; Fornasier, S.; White, K.M. Psychological Predictors of Young Adults' Use of Social Networking Sites. Cyberpsychology Behav. Soc. Netw. 2010, 13, 173-177. [CrossRef]

32. Griffiths, M. Nicotine, tobacco and addiction. Nature 1996, 384, 18. [CrossRef]

33. Griffiths, M. A 'components' model of addiction within a biopsychosocial framework. J. Subst. Use 2005, 10, 191-197. [CrossRef]

34. Ko, C.-H. Internet Gaming Disorder. Curr. Addict. Rep. 2014, 1, 177-185. [CrossRef]

35. Kuss, D.J.; Griffiths, M.; Karila, L.; Billieux, J. Internet Addiction: A Systematic Review of Epidemiological Research for the Last Decade. Available online: https:/www.ingentaconnect.com/content/ben/cpd/2014/ 00000020/00000025/art00006 (accessed on 2 December 2019).

36. Hu, L.; Bentler, P.M. Cutoff criteria for fit indexes in covariance structure analysis: Conventional criteria versus new alternatives. Struct. Equ. Model. Multidiscip. J. 1999, 6, 1-55. [CrossRef]

37. Peterson, R.A. A Meta-analysis of Cronbach's Coefficient Alpha. J. Consum. Res. 1994, 21, 381-391. [CrossRef]

38. Griffiths, M.; Kuss, D.J.; Demetrovics, Z. Chapter 6 - Social Networking Addiction: An Overview of Preliminary Findings. In Behavioral Addictions; Rosenberg, K.P., Feder, L.C., Eds.; Academic Press: San Diego, CA, USA, 2014; pp. 119-141.

39. Kircaburun, K.; Griffiths, M.D. Instagram addiction and the Big Five of personality: The mediating role of self-liking. J. Behav. Addict. 2018, 7, 158-170. [CrossRef] [PubMed] 
40. Higgins, J.P.T.; Green, S. Cochrane Handbook for Systematic Reviews of Interventions; John Wiley \& Sons: Hoboken, NJ, USA, 2011.

41. Callahan, D. The WHO Definition of "Health". Hastings Cent. Stud. 1973, 1, 77-87. [CrossRef] [PubMed]

42. Alheneidi, H. The influence of information overload and problematic Internet use on adults' well-being. Ph.D. Thesis, Cardiff University, Cardiff, UK, April 2019.

43. Atroszko, P.A.; Balcerowska, J.M.; Bereznowski, P.; Biernatowska, A.; Pallesen, S.; Schou Andreassen, C. Facebook addiction among Polish undergraduate students: Validity of measurement and relationship with personality and well-being. Comput. Hum. Behav. 2018, 85, 329-338. [CrossRef]

44. Brailovskaia, J.; Teismann, T.; Margraf, J. Physical activity mediates the association between daily stress and Facebook Addiction Disorder (FAD) - A longitudinal approach among German students. Comput. Hum. Behav. 2018, 86, 199-204. [CrossRef]

45. Du, J.; van Koningsbruggen, G.M.; Kerkhof, P. A brief measure of social media self-control failure. Comput. Hum. Behav. 2018, 84, 68-75. [CrossRef]

46. Olufadi, Y. Social networking time use scale (SONTUS): A new instrument for measuring the time spent on the social networking sites. Telemat. Inform. 2016, 33, 452-471. [CrossRef]

47. Satici, S.A. Facebook Addiction and Subjective Well-Being: a Study of the Mediating Role of Shyness and Loneliness. Int. J. Ment. Health Addict. 2019, 17, 41-55. [CrossRef]

48. Satici, S.A.; Uysal, R. Well-being and problematic Facebook use. Comput. Hum. Behav. 2015, 49, 185-190. [CrossRef]

49. Turel, O.; Poppa, N.; Tasha; Gil-Or, O. Neuroticism Magnifies the Detrimental Association between Social Media Addiction Symptoms and Wellbeing in Women, but Not in Men: A three-Way Moderation Model. Psychiatr. Q. 2018, 89, 605-619. [CrossRef]

50. Worsley, J.D.; Mansfield, R.; Corcoran, R. Attachment Anxiety and Problematic Social Media Use: The Mediating Role of Well-Being. Cyberpsychology Behav. Soc. Netw. 2018, 21, 563-568. [CrossRef]

51. Deci, E.L.; Ryan, R.M. Hedonia, eudaimonia, and well-being: An introduction. J. Happiness Stud. 2008, 9, 1-11. [CrossRef]

52. Kim-Prieto, C.; Diener, E.; Tamir, M.; Scollon, C.; Diener, M. Integrating The Diverse Definitions of Happiness: A Time-Sequential Framework of Subjective Well-Being. J. Happiness Stud. 2005, 6, 261-300. [CrossRef]

53. Huppert, F.A.; Baylis, N.; Keverne, B.; Ryff, C.D.; Singer, B.H.; Dienberg Love, G. Positive health: connecting well-being with biology. Philos. Trans. R. Soc. Lond. B. Biol. Sci. 2004, 359, 1383-1394.

54. Ryff, C.D.; Singer, B. Psychological Well-Being: Meaning, Measurement, and Implications for Psychotherapy Research. Psychother. Psychosom. 1996, 65, 14-23. [CrossRef] [PubMed]

55. Diener, E. What Is Positive about Positive Psychology: The Curmudgeon and Pollyanna. Psychol. Inq. 2003, 14, 115-120.

56. Seligman, M.E.P.; Csikszentmihalyi, M. Positive psychology: An introduction. Am. Psychol. 2000, 55, 5-14. [CrossRef]

57. Ryan, R.M.; Deci, E.L. On Happiness and Human Potentials: A Review of Research on Hedonic and Eudaimonic Well-Being. Annu. Rev. Psychol. 2001, 52, 141-166. [CrossRef]

58. Ryff, C.D.; Singer, B.H. Know Thyself and Become What You Are: A Eudaimonic Approach to Psychological Well-Being. J. Happiness Stud. 2008, 9, 13-39. [CrossRef]

59. Waterman, A.S.; Schwartz, S.J.; Zamboanga, B.L.; Ravert, R.D.; Williams, M.K.; Agocha, V.B.; Kim, S.Y.; Donnellan, M.B. The Questionnaire for Eudaimonic Well-Being: Psychometric properties, demographic comparisons, and evidence of validity. J. Posit. Psychol. 2010, 5, 41-61. [CrossRef]

60. Diener, E.; Emmons, R.A.; Larsen, R.J.; Griffin, S. The Satisfaction With Life Scale. J. Pers. Assess. 1985, 49, 71-75. [CrossRef] [PubMed]

61. Watson, D.; Clark, L.A.; Tellegen, A. Development and validation of brief measures of positive and negative affect: The PANAS scales. J. Pers. Soc. Psychol. 1988, 54, 1063-1070. [CrossRef] [PubMed]

62. Diener, E.; Wirtz, D.; Tov, W.; Kim-Prieto, C.; Choi, D.; Oishi, S.; Biswas-Diener, R. New Well-being Measures: Short Scales to Assess Flourishing and Positive and Negative Feelings. Soc. Indic. Res. 2010, 97, 143-156. [CrossRef]

63. Huppert, F.A.; So, T.T.C. Flourishing Across Europe: Application of a New Conceptual Framework for Defining Well-Being. Soc. Indic. Res. 2013, 110, 837-861. [CrossRef] [PubMed] 
64. Seligman, M.E.P. Flourish: A Visionary New Understanding of Happiness and Well-being; Atria Books: New York, NY, USA, 2012.

65. Vázquez, C.; Hervás, G.; Ho, S.M.Y. Intervenciones clínicas basadas en la Psicología Positiva: Fundamentos y aplicaciones. Psicol. Conduct. 2006, 14, 401-432.

66. Hinkle, D.E.; Wiersma, W.; Jurs, S.G. Applied statistics for the behavioral sciences, 5th ed.; Houghton Mifflin: Boston, MA, USA, 2003; ISBN 978-0-495-80885-5.

67. Lyubomirsky, S.; Lepper, H.S. A Measure of Subjective Happiness: Preliminary Reliability and Construct Validation. Soc. Indic. Res. 1999, 46, 137-155. [CrossRef]

68. Ryan, R.M.; Frederick, C. On Energy, Personality, and Health: Subjective Vitality as a Dynamic Reflection of Well-Being. J. Pers. 1997, 65, 529-565. [CrossRef]

69. Skevington, S.M.; Lotfy, M.; O'Connell, K.A. The World Health Organization's WHOQOL-BREF quality of life assessment: Psychometric properties and results of the international field trial. A Report from the WHOQOL Group. Qual. Life Res. 2004, 13, 299-310. [CrossRef]

70. Atroszko, P.A.; Andreassen, C.S.; Griffiths, M.D.; Pallesen, S. Study addiction - A new area of psychological study: Conceptualization, assessment, and preliminary empirical findings. J. Behav. Addict. 2015, 4, 75-84. [CrossRef]

71. Thayer, R.E. Activation-Deactivation Adjective Check List: Current Overview and Structural Analysis. Psychol. Rep. 1986, 58, 607-614. [CrossRef]

72. Topp, C.W.; Østergaard, S.D.; Søndergaard, S.; Bech, P. The WHO-5 Well-Being Index: A Systematic Review of the Literature. Psychother. Psychosom. 2015, 84, 167-176. [CrossRef] [PubMed]

73. Kashdan, T.B.; Biswas-Diener, R.; King, L.A. Reconsidering happiness: The costs of distinguishing between hedonics and eudaimonia. J. Posit. Psychol. 2008, 3, 219-233. [CrossRef]

74. Lukat, J.; Margraf, J.; Lutz, R.; van der Veld, W.M.; Becker, E.S. Psychometric properties of the Positive Mental Health Scale (PMH-scale). BMC Psychol. 2016, 4, 8. [CrossRef] [PubMed]

75. Williams, G.M.; Pendlebury, H.; Thomas, K.; Smith, A.P. The Student Wellbeing Process Questionnaire (Student WPQ). Psychology 2017, 8, 1748-1761. [CrossRef]

76. Ryff, C.D.; Keyes, C. The Structure of Psychological Well-Being Revisited. J. Pers. Soc. Psychol. 1995, 69, 719-727. [CrossRef]

77. Ryff, C.D. Happiness is everything, or is it? Explorations on the meaning of psychological well-being. J. Pers. Soc. Psychol. 1989, 57, 1069-1081. [CrossRef]

78. Williams, G.; Smith, A.P. A holistic approach to stress and well-being. Part 6: The Wellbeing Process Questionnaire (WPQ Short Form). Occup. Health Work 2012, 9, 29-31.

79. Graham, M.; Dutton, W.H. Society and the Internet: How Networks of Information and Communication are Changing Our Lives; Oxford University Press: Oxford, UK, 2019.

80. Monacis, L.; de Palo, V.; Griffiths, M.D.; Sinatra, M. Social networking addiction, attachment style, and validation of the Italian version of the Bergen Social Media Addiction Scale. J. Behav. Addict. 2017, 6, 178-186. [CrossRef]

81. Awata, S.; Bech, P.; Yoshida, S.; Hirai, M.; Suzuki, S.; Yamashita, M.; Ohara, A.; Hinokio, Y.; Matsuoka, H.; Oka, Y. Reliability and validity of the Japanese version of the World Health Organization-Five Well-Being Index in the context of detecting depression in diabetic patients. Psychiatry Clin. Neurosci. 2007, 61, 112-119. [CrossRef]

82. Furuya, M.; Hayashino, Y.; Tsujii, S.; Ishii, H.; Fukuhara, S. Comparative validity of the WHO-5 Well-Being Index and two-question instrument for screening depressive symptoms in patients with type 2 diabetes. Acta Diabetol. 2013, 50, 117-121. [CrossRef]

83. Young, K.S. Internet Addiction: A New Clinical Phenomenon and Its Consequences. Am. Behav. Sci. 2004, 48, 402-415. [CrossRef]

84. Hone, L.; Jarden, A.; Schofield, G. Psychometric Properties of the Flourishing Scale in a New Zealand Sample. Soc. Indic. Res. 2014, 119, 1031-1045. [CrossRef]

85. Durak, M.; Senol-Durak, E.; Gencoz, T. Psychometric Properties of the Satisfaction with Life Scale among Turkish University Students, Correctional Officers, and Elderly Adults. Soc. Indic. Res. 2010, 99, 413-429. [CrossRef]

86. Lepp, A.; Barkley, J.E.; Karpinski, A.C. The relationship between cell phone use, academic performance, anxiety, and Satisfaction with Life in college students. Comput. Hum. Behav. 2014, 31, 343-350. [CrossRef] 
87. Bunz, U.; Curry, C.; Voon, W. Perceived versus actual computer-email-web fluency. Comput. Hum. Behav. 2007, 23, 2321-2344. [CrossRef]

88. Williams, P.J. Technological literacy: A multliteracies approach for democracy. Int. J. Technol. Des. Educ. 2009, 19, 237-254. [CrossRef]

89. Eastin, M.S.; LaRose, R. Internet Self-Efficacy and the Psychology of the Digital Divide. J. Comput.-Mediat. Commun. 2000, 6, JCMC611. [CrossRef]

90. Kim, J.; Haridakis, P.M. The Role of Internet User Characteristics and Motives in Explaining Three Dimensions of Internet Addiction. J. Comput.-Mediat. Commun. 2009, 14, 988-1015. [CrossRef]

91. Gamberini, L.; Luciano; Alcañiz Raya, M.; Mariano; Barresi, G.; Giacinto; Fabregat; Malena; Ibanez; Gonçalves, F.; et al. Cognition, technology and games for the elderly: An introduction to ELDERGAMES Project. PsychNol. J. 2006, 4, 285.

92. Kirman, B.; Lawson, S.; Linehan, C.; Martino, F.; Gamberini, L.; Gaggioli, A. Improving Social Game Engagement on Facebook Through Enhanced Socio-contextual Information. In Proceedings of the Proceedings of the SIGCHI Conference on Human Factors in Computing Systems; ACM: New York, NY, USA, 2010; pp. 1753-1756.

93. Spagnolli, A.; Corradi, N.; Gamberini, L.; Hoggan, E.; Jacucci, G.; Katzeff, C.; Broms, L.; Jonsson, L. Eco-Feedback on the Go: Motivating Energy Awareness. Computer 2011, 44, 38-45. [CrossRef]

(C) 2020 by the authors. Licensee MDPI, Basel, Switzerland. This article is an open access article distributed under the terms and conditions of the Creative Commons Attribution (CC BY) license (http://creativecommons.org/licenses/by/4.0/). 